\title{
Dose Effect of Rhenium (I)-diselenoether as Anticancer Drug in Resistant Breast Tumor-bearing Mice After Repeated Administrations
}

\author{
PHILIPPE COLLERY ${ }^{1,2}$, FRANÇOIS SANTONI ${ }^{2,3}$, JOSEPH CICCOLINI ${ }^{4}$, \\ THI NGOC NGA TRAN ${ }^{4}$, AHMED MOHSEN $^{5}$ and DIDIER DESMAELE ${ }^{5}$ \\ ${ }^{1}$ Society for the Coordination of Research, Algajola, France; \\ ${ }^{2}$ Association of Research and Development Center for the Therapeutic \\ Use of Organo-Metallic Compounds, Polyclinic Maymard, Bastia, France; \\ ${ }^{3}$ Laboratory of the Corsican Office of Hydraulic Equipment, Bastia, France; \\ ${ }^{4}$ SMARTc - Simulation and Modeling: Adaptative Response for Therapeutics in Cancer, \\ UMR INSERM 911, Faculty of Pharmacy University of Aix-Marseille, Marseille, France; \\ ${ }^{5}$ UMR CNRS 8612, Galien Institute, Faculty of Pharmacy, University Paris-Saclay, Châtenay-Malabry, France
}

\begin{abstract}
Rhenium (I)-diselenoether has shown promising antiproliferative efficacy in both in vitro and in vivo models. However, the maximal tolerated dose and dose-effect relationships have not been fully addressed for this compound. Here, we evaluated the tolerance and efficacy of three dose-levels (namely 10, 40 and $100 \mathrm{mg} / \mathrm{kg}$ ) intraperitoneally administered daily over 28 days in mice bearing the resistant MDA-MB231 breast cancer cell line. The upper dose was found to be toxic and was reduced to $60 \mathrm{mg} / \mathrm{kg}$. The $10 \mathrm{mg} / \mathrm{kg}$ dose well tolerated, whereas $40 \mathrm{mg} / \mathrm{kg}$ was associated with $10 \%$ mortality $\left(L D_{10}\right)$. Both 10 and $40 \mathrm{mg} / \mathrm{kg}$ dosing achieved a significantly similar regression of tumor growth compared with untreated animals. This study suggests that $10 \mathrm{mg} / \mathrm{kg}$ daily is the recommended dose for rhenium (I) diselenoether.
\end{abstract}

Rhenium(I)-diselenoether has been proposed as an anticancer agent (1-6). This compound features a central atom of rhenium bound to 3,7-diselenanonanedioic acid ligand in which the two selenium atoms secure a tight complexation of the $\mathrm{Re}$, while the carboxylic group, as sodium salt, allows water solubility. This amphiphilic

This article is freely accessible online.

Correspondence to: Philippe Collery, Société de Coordination de Recherches Thérapeutiques, 20220 Algajola, France. E-mail: philippe.collery@gmail.com

Key Words: Rhenium ( $\mathrm{Re})$, selenium (Se), in vivo experiment, MDA-MB231, bioluminescence, mice, breast cancer. complex is a hydrophilic drug, soluble in water, easy to administer and lipophilic with a good distribution in tissues after oral administration (2).

Re is a heavy transition metal (atomic number 75, atomic mass $186.21 \mathrm{~g} / \mathrm{mol}$ ), with the widest range of oxidation states of any element $(-3,-1,+1,+2,+3,+4,+5,+6+7)$, providing it with unique properties. It was demonstrated with Re-diselenoether drug that Re formed DNA adducts with one or two guanine bases (3), like cisplatin, but with an octahedral configuration and not a square-planar one. The uptake of $\mathrm{Re}$ in the nucleus of malignant cells has also been demonstrated after exposure to Re-diselenoether complex (2). Other Re-based drugs have also shown a high activity against a variety of tumor cell lines, with a good selectivity for cancer cells $(7,8)$. One common mechanism of action could be related to the binding of $\mathrm{Re}$ with guanine and adenine bases of DNA (9-12). In contrast with cisplatin, the binding with the DNA bases is reversible (13). Re also binds with proteins $(14,15)$. However, other properties of $\mathrm{Re}$ compounds have been identified, like the inhibition of some cysteine proteases (16). We hypothesize that the Re atom could be used either for oxidation or reduction of cell components due to its great number of oxidation states. Re cluster compounds were screened for their biological activities as antioxidants (17) and proposed to protect erythrocytes from hemolytic anemia (18). These $\mathrm{Re}$ compounds affected the peroxidation level, the activity of superoxide dismutase, the antioxidant factor and the index of resistance of erythrocytes to hemolysis as a function of the concentration range in the pre-incubation medium of erythrocytes $(19,20)$. Due to these antioxidant properties, $\mathrm{Re}$ 
cluster compounds have been proposed for use in avoiding cisplatin-induced anemia (21). This was demonstrated in animal models with tumor-bearing rats, as was a synergism between cisplatin and Re (III) diadamantate (22) and with dichlorotetra- $\mu$-isobutyratodirhenium (III) complex (23) and the cluster Re compound with gamma-aminobutyric acid ligand (24). This synergism was however not observed with the $\operatorname{Re}(\mathrm{I})$-diselenoether complex $(4,3)$, but the schedule of treatments were different.

Selenium (Se) provides additional biological properties. A non-metal, Se has an atomic number of 34 and atomic mass of $78.96 \mathrm{~g} / \mathrm{mol}$. This element also has several states of oxidation $(-2,0,+4,+6)$. Se is found in selenoproteins (glutathione peroxidases, thioredoxin reductases, selenoproteins $\mathrm{P}$ and $\mathrm{W}$, iododeionidase reductase, selenophosphate synthetase) incorporated in the form of selenocysteines (25-30). Selenocysteine is metabolized into methylselenol $\left(\mathrm{CH}_{3}-\mathrm{SeH}\right)$, which possesses strong nucleophilicity (31) and stronger potential for inhibiting cell proliferation/survival signals in colon cancer-derived HCT-116 cells when compared to that in non-cancerous colon NCM460 cells (32). Anti-angiogenic properties of $\mathrm{Se}$ compounds have been related to the methylselenol derivative (33). Selenol derivatives act as reducing agents to give selenic acid derivatives, which are again reduced by enzymes containing thiols. The oxidation of cysteine, especially its thiol or thiolate groups, has been described as a major event involved in modifying the function of signaling proteins and cysteine redox post-translational modifications affect protein structure and function $(34,35)$. On the other hand, organo-Se compounds modulate extracellular redox by induction of extracellular cysteine and cell-surface thioredoxin reductase (36). The administration of Se drugs may induce either oxidant or antioxidant effects in the cells (37-39) by oxidation or reduction of thiol-containing proteins, depending on the influence of neighboring groups and redox potential (31). Se is essential for antioxidant activity but may have pro-oxidant properties at higher concentrations. This was clearly shown with Se-methionine in human immortalized keratinocytes by Hazane-Puch et al. (40). These cells were exposed for $144 \mathrm{~h}$ to Se-methionine and then either to UVA radiation or not. The $10 \mu \mathrm{M}$ dose was non-toxic, protecting the cells from UVA-induced cell death, while the $100 \mu \mathrm{M}$ dose was toxic, causing caspase-3-dependent apoptosis. The nontoxic dose was antioxidant, with an increase in selenoprotein glutathione peroxidase 1 (GPX1) activity and an increase in selenoprotein-1 transcript expression. The toxic dose, which did not protect the cells from UVA damage but inhibited cell proliferation through $\mathrm{S}-\mathrm{G}_{2}$ blockage, a decrease in mitochondrial transmembrane potential and a DNA fragmentation, was oxidant with production of hydrogen peroxide. Another study demonstrated that Se yeast selectively inhibited the growth of breast cancer cell lines and not of nontumorigenic human mammary cells (41). In contrast, methylselenic acid also inhibited the growth of normal cell lines. It also had greater inhibitory effects, with a higher production of reactive oxygen species (ROS) levels than Se yeast at doses of 1.3 or 9.5 and $19 \mu \mathrm{M} \mathrm{Se}$, but with a loss of selectivity. The authors proposed the existence of differential redox potential between normal and cancer cells as previously noted by Trachootam et al. (42). Selenoprotein antioxidant protection in non tumor cells could explain these results.

Thus, the main mechanism of action of $\mathrm{Re}$ and $\mathrm{Se}$ on malignant cells could be by interfering with their redox system.

Re-diselenoether was already shown to be active against breast malignant cells in culture and the inhibitory effect persisted after the interruption of the exposure to the drug (3). A dose of $10 \mu \mathrm{M}$ Re-diselenoether did not inhibit the growth of human hormone-independent breast cancer cell line (MDA-MB231) after an exposure of $48 \mathrm{~h}$, but a dose of $40 \mu \mathrm{M}$ completely inhibited their growth (3). An experimental animal study in MDA-MB231 tumor-bearing mice showed that an oral daily administration of 10 $\mathrm{mg} / \mathrm{kg} / 24 \mathrm{~h}$ Re-diselenoether for 4 weeks was very effective and not toxic to the mice (3).

Here we report a new experiment with the same model of MDA-MB231 transplantation in nude mice, using three doses of Re-diselenoether, in order to determine the relationship between dose and the efficacy, as well as toxicity, after repeated intraperitoneal (i.p.) injections.

\section{Materials and Methods}

This experiment was performed at the Laboratory of Toxicokinetics and Pharmacokinetics at the Faculty of Pharmacy of Marseille University. The protocol was submitted to both the French Ministry of Health and Aix Marseille University local Ethics Committee for approval (number 02151.01).

Triple-negative breast cancer MDA-MB231 cells (Caliper LS, Villebon sur Yvette, France), stably transfected with the luciferase gene (Luc+) to allow the imaging of the primary tumors by bioluminescence, were orthotopically implanted into the mammary gland (fat pad) in nude mice. They were orthotopically inoculated at the dose of 200.000 cells per mouse in 50 six-week-old female Swiss nude mice (Charles River, Ecully, France) with the use of $60 \%$ matrigel. Grafting rate was $95 \%$, assessed by a first imaging by bioluminescence at day 6 after the inoculation of the tumor cells. From the mice with positive imaging, 40 mice were randomized into four groups of 10 mice: a control group receiving a saline vehicle and three groups treated by Re (I)-diselenoether complex (Galien Institute, Châtenay-Malabry, France). The treatments were administered to the MDA-M231 tumor bearing-mice, daily. Three doses were initially investigated,10, 40 and $100 \mathrm{mg} / \mathrm{kg}$ and treatments began 9 days after tumor grafting. Initial administration was initially expected to be per os after supplementing food with Re (I)-diselenoether, but observations suggested that the intake could be erratic by this means and it was decided to stop the oral administration at day 16 and to change to i.p. injections after a wash-out period of 4 days. The treatments were then continued as i.p. injections from day 20 until day 44 for all groups. 


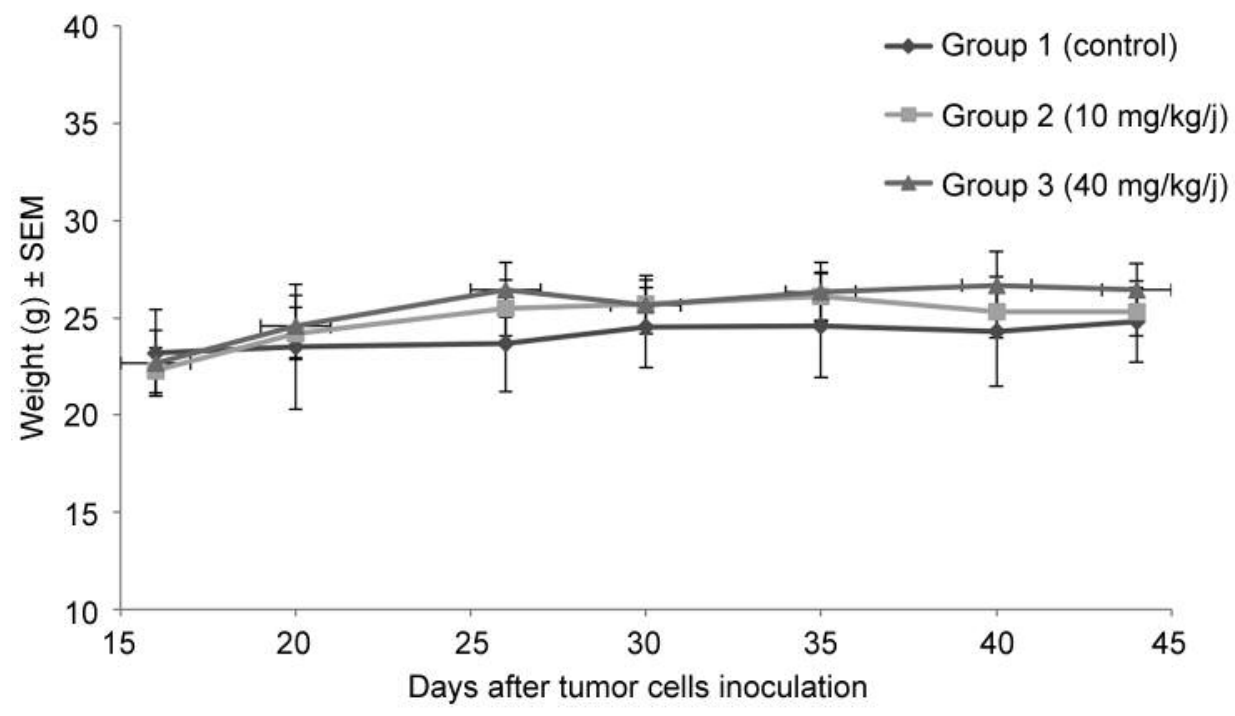

Figure 1. Evolution of mouse weight (mean \pm SEM) after administration of Re (I) diselenoether (10 and $40 \mathrm{mg} / \mathrm{kg} / \mathrm{d})$ versus controls. No statistically significant difference was found in carcass weight at study conclusion (one-way Anova, $p=0.108$ ).

The evaluation of the tumor mass was based on bioluminescence measurements using 2D imaging twice a week. For that purpose, $150 \mathrm{mg} / \mathrm{kg}$ luciferin was injected into the mice 12 minutes prior to image acquisition, resulting in a luciferase-induced oxidation of luciferin into oxyluciferin. This oxidation was accompanied by the emission of photons at $560 \mathrm{~nm}$ (visible light), which were quantized. The IVIS ${ }^{\circledR}$ Spectrum (Perkin Elmer) high-throughput 2D optical imaging system was used to quantitatively evaluate the tumor mass. The evaluation of the toxicity was measured by the weight of the animals, twice a week. Deaths were also reported.

Statistics. Statistical evaluation of the antitumor effect was assessed by ANOVA test (one-way ANOVA on the ranks), using Sigma Stat, USA.

\section{Results}

Toxicity. Signs of animal distress were rapidly observed in the group treated with $100 \mathrm{mg} / \mathrm{kg}$ as early as the day after the first i.p. injection. Despite stopping administration, six out of the 10 animals had to be sacrificed following standard procedures. The four remaining animals were then treated at an intermediary dose of $60 \mathrm{mg} / \mathrm{kg}$ with no further death until the end of the experiment. The $60-\mathrm{mg} / \mathrm{kg}$ dose can be considered as the maximum tolerated dose (MTD) for 4week daily i.p. administration. After the protocol amendment, a complementary dose-finding study performed on a satellite group of mice not included in the treatment groups confirmed that $75 \mathrm{mg} / \mathrm{kg}$ was the $50 \%$ lethal dose $\left(\mathrm{LD}_{50}\right)$ dose after repeated i.p. injections (data not shown). Despite no clinical or paraclinical sign of distress, one death occurred in the group treated with $40 \mathrm{mg} / \mathrm{kg}, 6$ days after the first i.p. injection, thus suggesting this could be the $\mathrm{LD}_{10}$ level. The $10 \mathrm{mg} / \mathrm{kg}$-treated group showed no signs of toxicity and this may represent the no-adversed toxicity level. Monitoring of body weight during the study showed no significant difference in carcass weight between the treated and control mice (Figure 1) at study conclusion (oneway ANOVA, $p=0.108$ ). However, on day 26 , mice from the control group had mean weight significantly smaller than the treatment groups $(p=0.012)$.

Efficacy. Because of the change in dosing and reduction of the sample size impacting on statistical power, the group treated with $100(60) \mathrm{mg} / \mathrm{kg}$ was not included in the efficacy study. The experimental data obtained by $2 \mathrm{D}$ imaging showed an early statistically significant decrease of the tumor volumes in treated mice, with a $43 \%$ reduction for mice treated at $10 \mathrm{mg} / \mathrm{kg}$ at day $26(p<0.001)$ versus controls and a $72 \%$ reduction for mice treated at $40 \mathrm{mg} / \mathrm{kg}$ versus controls $(p<0.001)$ during the early phase of tumor growth, while tumors were in exponential growth (Figure 2). The data indicate the persistence of a statistically significant tumor growth inhibition at both 10 and $40 \mathrm{mg} / \mathrm{kg}(p<0.05)$ versus controls throughout the experiment. The lack of significant difference between these two doses was evidenced from the growth curves at both dose levels seeming to merge from day 30 until the end of the experiment.

In this study, few metastases were observed: $2 / 10$ in the control group; $1 / 10$ in mice treated at the dose of $10 \mathrm{mg} / \mathrm{kg}$; and $1 / 9$ in mice treated at the dose of $40 \mathrm{mg} / \mathrm{kg}$. It was not possible to perform a statistical test on the incidence of mice presenting with metastasis. 


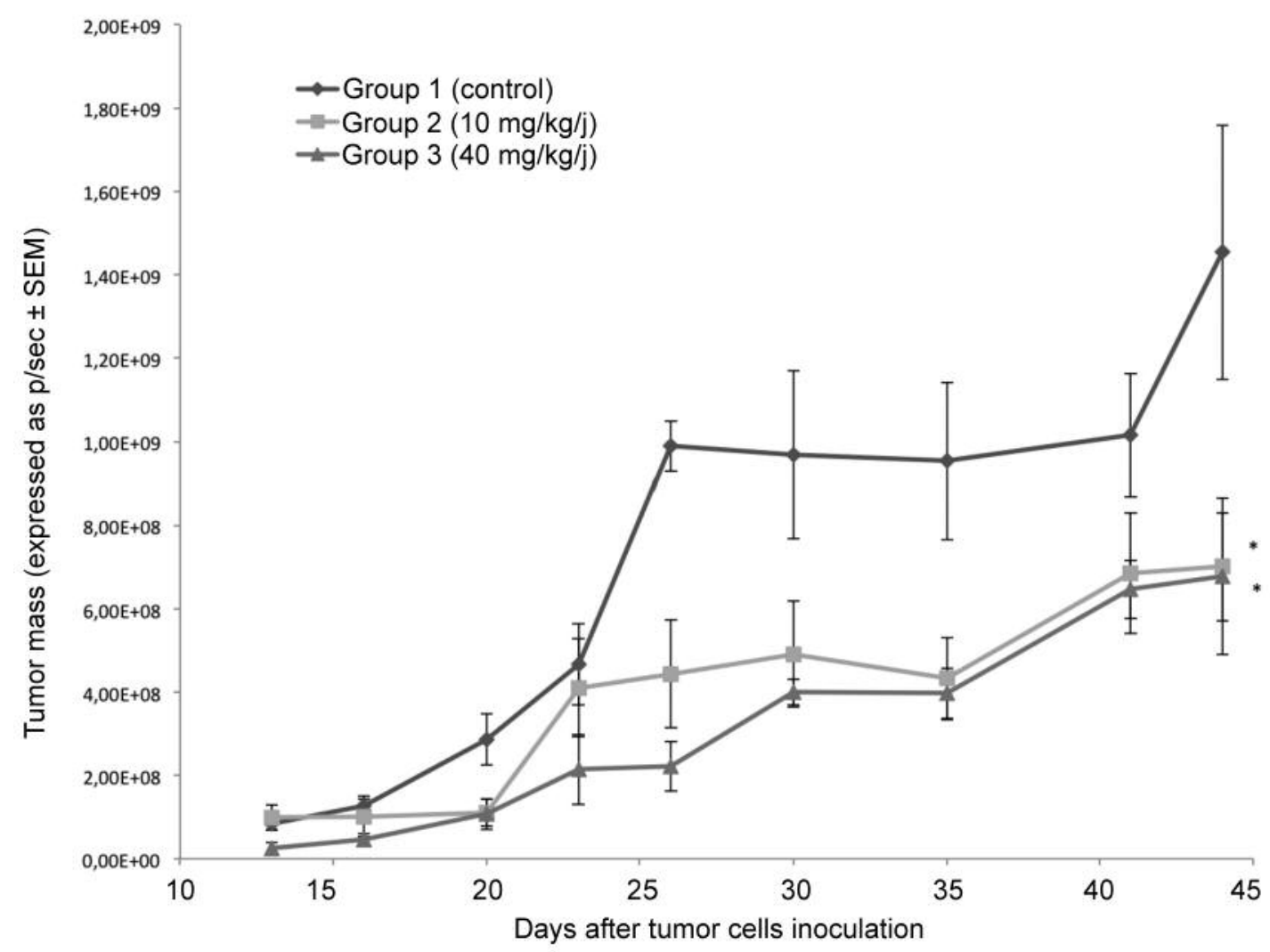

Figure 2. Evolution of the tumor mass as evaluated by $2 D$ bioluminescence (photons/second) after daily i.p. administration of Re (I)-diselenoether (10 and $40 \mathrm{mg} / \mathrm{kg} / \mathrm{d}$ ) versus controls. Analysis of the curves by ANOVA tests (one-way ANOVA with Newman Keuls multiple comparison testing) showed that tumor masses were statistically different $(p<0.05)$ in treated groups $2(10 \mathrm{mg} / \mathrm{kg})$ and $3(40 \mathrm{mg} / \mathrm{kg})$ versus control group 1 , but not between groups 2 and 3 . *Statistically different from the control group.

\section{Discussion}

In a previous published study, Re-diselenoether complex induced remarkable antitumor activity with nearly complete regression of the tumors at the site of the primary tumors and a statistically significant decrease in the number of pulmonary metastases after a daily oral dose of $10 \mathrm{mg} / \mathrm{kg}$ for 4 weeks (3). The aim of this study was to investigate whether increasing the dosing of Re-diselenoether complex would further improve its antiproliferative efficacy. We confirm here the antitumor activity of the Re-diselenoether at the same daily dose of $10 \mathrm{mg} / \mathrm{kg}$ for 4 weeks after i.p. injection. In this new experiment, matrigel was used to improve the transplantation rate of the primary tumors, but few metastases were noted. It is known that matrigel increases the aggressiveness of transplanted tumors (43) and even the amount of matrigel has a great influence on tumor growth. Matrigel is a basement membrane-like extracellular matrix extract, mainly composed of laminin, collagen IV, heparan sulfate proteoglycan, but also of various growth factors such as fibroblast growth factor, transforming growth factor beta, epidermal growth factors and others. These components greatly accelerate tumor growth. The use of matrigel can therefore explain why the tumor growth decreased but was not inhibited as it was in the previously published study. Only few metastases were found in this study, probably because of the strain (Swiss nude) of the mice which are not totally immune-compromised.

One important result of this study is the lack of benefit when increasing the dose from 10 to $40 \mathrm{mg} / \mathrm{kg}$. This observation suggests that there was a weak dose-efficacy relationship, at least above the $10 \mathrm{mg} / \mathrm{kg}$ dose level. In this respect, treating animals at the MTD (i.e. $40 \mathrm{mg} / \mathrm{kg}$ ) has little relevance. In addition, $75 \mathrm{mg} / \mathrm{kg}$ was identified as the $\mathrm{LD}_{50}$ level. In a previous study, three doses of Re-diselenoether were tested in combination with cisplatin and a gallium compound (4): increasing the Re-diselenoether dose from 10 to $50 \mathrm{mg} / \mathrm{kg}$, as an oral administration for 3 weeks, did not improve the efficacy but greatly increased the toxicity. In 1998, it was demonstrated that the protective effects of Se compounds against UV toxicity in keratinocytes and melanocytes were observed at low 
concentrations, between 1 and $200 \mathrm{nM}$, and no protective effects were observed with concentrations higher than $1 \mu \mathrm{M}$ (44). These effects were related to the detoxification of free radicals by Se-induced production of glutathione peroxidases. One main objective now will be to investigate if lower doses might also be effective. The toxicity and bioavailability of oral doses will also have to be compared with those resulting from i.p. injections. The toxicity may be completely different according to the mode of administration, as well as the metabolism and bioavailability.

Doses may have to be adjusted according to parameters other than the body weight. It is expected that Rediselenoether could be considered as a modulator of the redox potential. Cancer cells, particularly breast cancer cells, have a pro-oxidant status, resulting from the high production of free radicals (45). Oxidative stress reflects an imbalance between the production of free radicals and anti-oxidant defense. Free radicals include ROS and reactive nitrogen species. Anticancer drugs usually enhance this pro-oxidant status as the high production of free radicals will kill the cancer cells. However, this will also induce toxic effects. This is not the case with the use of trastuzumab, a monoclonal antibody effective against breast cancer overexpressing human epidermal growth factor receptor 2 (HER2), which reduced the redox potential of these cells (46). Studies showed that the molecular subtypes of cancer cells can be determined by their redox status (46). The distinction between luminal type cancer, cells expressing HER2 and triple-negative cancer cells was reportedly related not only to the oxidative status, but also to the markers of inflammation in another publication (47), with high levels of lipidic peroxidation and of nitric oxide for triple-negative cancer. The pro-oxidant status is more pronounced when the cancer stage is more advanced (48) and under the effects of chemotherapeutic agents such as doxorubucin or paclitaxel (49). A decrease of the content of antioxidant enzymes in cancer cells reduces the efficacy of chemotherapy with carboplatin/paclitaxel (50). A relationship was observed between the degree of resistance to cytotoxic drug and the oxidative system in a cisplatin-resistant prostate cancer model (51). All these studies show the importance of investigating oxidative stress in patients with cancer. It could then be proposed to adapt the doses of anticancer drugs according to the redox status. Pro-oxidant doses, expected with the highest doses, will be toxic and the damage induced by free radicals are well known. Antioxidant doses, at lower doses, may actually favor tumor growth if they are not high enough to inhibit the growth of the cancer cells. ROS within cells act as secondary messengers in intracellular signaling cascades, which induce and maintain the oncogenic phenotype of cancer cells, in particular, by ROS activation of activator protein-1 and nuclear factor kappa B signal transduction pathways, which in turn leads to the transcription of genes involved in cell growth-regulatory pathways $(52,53)$. Normalizing the level of production of ROS by Re-diselenoether may then reduce these effects.

Plasma Se, copper and zinc may be used to investigate the antioxidant status. These markers could then be useful to define the dose of Re-diselenoether to be administered to patients with cancer. The doses will obviously also be determined by toxicological studies. There are few data on Re toxicity but it seems to be low (54). Se toxicity mainly depends on the chemical form and organic Se compound is less toxic than inorganic salts (55). Most clinical trials with Se compounds are performed with doses of $200 \mu \mathrm{g} / 24 \mathrm{~h}$ of Se element, but failed to demonstrate an effect in the prevention of cancer, except in individuals with low plasma Se levels at the beginning of the treatment and this was the case in the Nutritional Prevention of Cancer trial (56). The reduction of the risk of cancer was significantly observed only in those with plasma Se levels lower than $106 \mu \mathrm{g} / \mathrm{l}$ before the beginning of the treatment with 200 $\mu \mathrm{g} / 24 \mathrm{~h}$ yeast enriched with Se. In contrast, in those with plasma Se levels higher than $121 \mu \mathrm{g} / \mathrm{l}$ before treatments, the risk of cancer was significantly increased. The percentage of Se in Re-diselenoether is $23.65 \%$. In $10 \mathrm{mg} / \mathrm{kg}$ of Re-diselenoether is therefore $2.4 \mathrm{~g}$ of Se. The known toxicity of Se in humans is an additional reason for preferentially investigating doses lower than $10 \mathrm{mg} / \mathrm{kg}$ Re-diselenoether, as suggested by our experiment. Plasma Se levels may be also very useful for monitoring toxicity. Plasma Se concentrations may also reflect the effect of the drug on angiogenesis, as it was report that a decrease in plasma Se levels in breast tumor-bearing mice was associated with a decrease in glutathione peroxidase activity in plasma and was correlated with higher plasma vascular endothelial growth factor and malondialdehyde concentrations (57). The plasma Se concentration could therefore be a simple marker for determining which patients will benefit from Rediselenoether treatment, monitoring the dose and for controlling efficacy.

\section{Conclusion}

A daily dose of $10 \mathrm{mg} / \mathrm{kg}$ of Re-diselenoether can be considered safe for Swiss nude mice, by oral or by i.p. route for a 4-week treatment period. It allowed a significant antitumor effect and the recommended dose previously published (3) is confirmed. After i.p. injections, higher doses will not increase the efficacy but the toxicity. Doses lower than $10 \mathrm{mg} / \mathrm{kg} / 24 \mathrm{~h}$ need be tested as they may be as effective, including as part of metronomic scheduling. The schedule of treatment could take into account the redox status noted in patients with cancer. For this, treatment could be monitored by markers of the oxidative system and, among them, the plasma Se concentration. The model of MDA-MB231 transplanted tumor corresponds to the treatment of patients with metastatic non hormono-sensitive breast cancer, especially triple-negative 
cancer, but the treatment could perhaps also be targeted by the redox status level in other types of cancer.

\section{Acknowledgements}

The Authors would like to thank the La Marie Do association from Corsica, for their great moral and financial support.

\section{References}

1 Kermagoret A, Morgant G, D’Angelo J, Tomas A, Roussel P, Bastian G, Collery P and Desmaële D: Synthesis, structural characterization and biological activity against several human tumor cell lines of four rhenium(I) diseleno-ether complexes: $\mathrm{Re}(\mathrm{CO}) 3 \mathrm{Cl}(\mathrm{PhSe}(\mathrm{CH} 2) 2 \mathrm{SePh}), \mathrm{Re}(\mathrm{CO}) 3 \mathrm{Cl}(\mathrm{PhSe}(\mathrm{CH} 2) 3 \mathrm{SePh})$, $\mathrm{Re}(\mathrm{CO}) 3 \mathrm{Cl}(\mathrm{HO} 2 \mathrm{C}-\mathrm{CH} 2 \mathrm{Se}(\mathrm{CH} 2) 2 \mathrm{SeCH} 2-\mathrm{CO} 2 \mathrm{H})$ and $\mathrm{Re}(\mathrm{CO})$ $3 \mathrm{Cl}(\mathrm{HO} 2 \mathrm{C}-\mathrm{CH} 2 \mathrm{Se}(\mathrm{CH} 2) 3 \mathrm{SeCH} 2-\mathrm{CO} 2 \mathrm{H})$. Polyhedron 30: 347354, 2011.

2 Collery P, Bastian G, Santoni F, Mohsen A, Wei M, Collery T, Tomas A, Desmaele D and D'Angelo J: Uptake and efflux of rhenium in cells exposed to rhenium diseleno-ether and tissue distribution of rhenium and selenium after rhenium diselenoether treatment in mice. Anticancer Res 34: 1679-1690, 2014.

3 Collery P, Mohsen A, Kermagoret A, Corre S, Bastian G, Tomas A, Wei M, Santoni F, Guerra N, Desmaele D and d'Angelo J: Antitumor activity of a rhenium (I)-diselenoether complex in experimental models of human breast cancer. Invest New Drugs 33: 848-860, 2015.

4 Collery P, Mohsen A, Kermagoret A, D’Angelo J, Morgant G, Desmaele D, Tomas A, Collery T, Wei M and Badawi A: Combination of three metals for the treatment of cancer: gallium, rhenium and platinum. 1- determination of the optimal schedule of treatment. Anticancer Res 32: 2769-2782, 2012.

5 Collery P, D'Angelo J and Morgant G: Rhenium complexes and their pharmaceutical use- European Patent $\mathrm{N}^{\circ}$ 2575800. In: European Patent Bulletin 15/03 of 14.01.2015 (Office EP ed.).

6 Collery P, D'Angelo J and Morgant G: Rhenium complexes and their pharmaceutical use- US Patent $N^{\circ}$ 8987491B2. In: March 24, 2015 (Patent US ed.).

7 Leonidova A and Gasser G: Underestimated potential of organometallic rhenium complexes as anticancer agents. ACS chemical biology 9: 2180-2193, 2014.

8 Ashok Kumar C, Nagarajaprakash R, Victoria W, Veena V, Sakthivel N and Manimaran B: Synthesis, characterisation and cytotoxicity studies of manganese(I) and rhenium(I) based metallacrown ethers. Inorganic Chemistry Communications 64 : 39-44, 2016.

9 Adams KM and Marzilli LG: fac-[Re(CO)3(H2O)3]+ nucleoside monophosphate adducts investigated in aqueous solution by multinuclear NMR spectroscopy. Inorg Chem 46: 4926-4936, 2007.

10 Adams KM, Marzilli PA and Marzilli LG: Reactions of fac$[\operatorname{Re}(\mathrm{CO}) 3(\mathrm{H} 2 \mathrm{O}) 3]+$ with nucleoside diphosphates and thiamine diphosphate in aqueous solution investigated by multinuclear NMR spectroscopy. Inorg Chem 46: 9172-9181, 2007.

11 Zobi F, Blacque O, Schmalle HW, Spingler B and Alberto R: Head-to-head (HH) and head-to-tail (HT) conformers of cis-bis guanine ligands bound to the $[\operatorname{Re}(\mathrm{CO}) 3]+$ core. Inorg Chem 43: 2087-2096, 2004.
12 Prater ME, Mindiola DJ, Ouyang X and KRD: A quadruplybonded dirhenium complex bridged by two N1/N6 adenate ligands. Inorganic Chemistry Communications 1: 475-477, 1998.

13 Zobi F, Spingler B, Fox T and Alberto R: Toward novel DNA binding metal complexes: structure and basic kinetic data of $[\mathrm{M}(9 \mathrm{MeG}) 2(\mathrm{CH} 3 \mathrm{OH})(\mathrm{CO}) 3]+(\mathrm{M}=99 \mathrm{Tc}, \mathrm{Re})$. Inorg Chem 42 : 2818-2820, 2003.

14 Binkley SL, Leeper TC, Rowlett RS, Herrick RS and Ziegler CJ: $\operatorname{Re}(\mathrm{CO})(3)(\mathrm{H}(2) \mathrm{O})(3)(+)$ binding to lysozyme: structure and reactivity. Metallomics 3: 909-916, 2011.

15 Zobi F and Spingler B: Post-protein-binding reactivity and modifications of the fac-[Re(CO)3]+ core. Inorg Chem 51: 12101212, 2012.

16 Fricker SP: Cysteine proteases as targets for metal-based drugs. Metallomics 2: 366-377, 2010.

17 Shtemenko N, Pirozhkova-Patalah IV and Shtemenko A: Screening and testing strategy for biological activity of rhenium cluster compounds. In: Metal Ions in Biology and Medicine. J.A. Centeno, P. Collery, G. Vernet, R.B. Finkelman, H. Gibb, J.C. Etienne (eds.). John Libbey Eurotext, Paris, 6: pp. 616-618, 2000.

18 Shtemenko A, Shtemenko N, Oliyvnyk SA and Zelenuk MA: Lyposome forms of rhenium cluster compounds in models of haemolytic anemia. In: Metal Ions in Biology and Medicine. Khassanova L, Collery P, Maymard I, Khassanova Z, Etienne JC (eds.). John Libbey Eurotext, Paris 7: 558-561, 2002.

19 Pirozhkova-Patalah IV and Shtemenko NI: Influence of cis[Re2GABA2Cl4]Cl2 on the antioxidant defense system parameters of normal human blood. Biochemistry 66: 721-724, 2001.

20 Leus I, Zabitskaya E, Collery P, Shamelashvili K, Yegorova D and Shtemenko N: Investigation of antioxidant properties of the cluster rhenium compound in the model of tumor growth. In: Metal Ions in Biology and Medicine, Eds Collery P, Maymard I, Theophanides T, Khassanova L and Collery T (eds.). John Libbey Eurotext, Paris 10: 399-402, 2008.

21 Collery P, Shtemenko N, Shtemenko A, Bourleaud M, Etienne JC, Maymard I and Loriquet P: Supplementation by rhenium compounds instead of iron compounds during the treatment by erythropoietin of anemia in cancer patients. Cser MA, Sziklai Laszlo I, Etienne J C, Maymard I, Centeno J, Khassanova L and Collery P (eds.). In: Metal Ions in Biology and Medicine, John Libbey Eurotext, Paris 8: 534-537, 2004.

22 Shtemenko N, Collery Ph and Shtemenko A: Synergistic effect of cisplatin and cis-rhenium (III) diadamantate on tumor growth. Alpoim MC,Vasconcellos Morais P, Santos MA, Cristovao AJ, Centeno JA and Collery Ph (eds.) In: Metal Ions in Biology and Medicine John Libbey Eurotext, Paris 9: 374-381, 2006.

23 Shtemenko N, Collery P and Shtemenko A: Dichlorotetra- $\mu-$ isobutyratodirhenium (III): enhancement of cisplatin action and RBC-stabilizing properties. Anticancer Res 27: 2487-2492, 2007.

24 Shtemenko AV, Collery P, Shtemenko NI, Domasevitch KV, Zabitskaya ED and Golichenko AA: Synthesis, characterization, in vivo antitumor properties of the cluster rhenium compound with GABA ligands and its synergism with cisplatin. Dalton Trans 26: 5132-5136, 2009.

25 Hill KE, Wu S, Motley AK, Stevenson TD, Winfrey VP, Capecchi MR, Atkins JF and Burk RF: Production of selenoprotein P (SEPP1) by hepatocytes is central to selenium homeostasis. J Biol Chem 287: 40414-40424, 2012. 
$26 \mathrm{Lu}$ J and Holmgren A: Selenoproteins. J Biol Chem 284: 723 727, 2009.

27 Papp LV, Holmgren A and Khanna KK: Selenium and selenoproteins in health and disease. Antioxid Redox Signal 12: 793-795, 2010.

28 Rayman MP: Selenium and human health. Lancet 379: 12561268,2012

29 Zhuo P and Diamond AM: Molecular mechanisms by which selenoproteins affect cancer risk and progression. Biochim Biophys Acta 1790: 1546-1554, 2009.

30 Bellinger FP, Raman AV, Reeves MA and Berry MJ: Regulation and function of selenoproteins in human disease. Biochem $\mathrm{J} 422$ : 11-22, 2009

31 Park E-M, Choi K-S, Park S-Y, Kong E-S, Zu K, Wu Y, Zhang H, Ip C and Y-M P: A display thiol-proteomics approach to characterize global redox modification of proteins by selenium: implications for the anticancer action of selenium. Cancer Genomics Proteomics 2: 25-36, 2005.

32 Zeng $\mathrm{H}$, Briske-Anderson $\mathrm{M}$, Wu $\mathrm{M}$ and Moyer MP: Methylselenol, a selenium metabolite, plays common and different roles in cancerous colon HCT116 cell and noncancerous NCM460 colon cell proliferation. Nutr Cancer 64: 128-135, 2012.

33 Font M, Zuazo A, Anso E, Plano D, Sanmartin C, Palop JA and Martinez-Irujo JJ: Novel structural insights for imidoselenocarbamates with antitumoral activity related to their ability to generate methylselenol. Bioorg Med Chem 20: 5110-5116, 2012.

34 Wani R, Nagata A and Murray BW: Protein redox chemistry: posttranslational cysteine modifications that regulate signal transduction and drug pharmacology. Front Pharmacol 5: 224, 2014.

35 Poole LB: The basics of thiols and cysteines in redox biology and chemistry. Free Radic Biol Med 80: 148-157, 2015.

36 Zhang G, Nitteranon V, Guo S, Qiu P, Wu X, Li F, Xiao H, Hu Q and Parkin KL: Organoselenium compounds modulate extracellular redox by induction of extracellular cysteine and cell surface thioredoxin reductase. Chem Res Toxicol 26: 456-464, 2013.

37 Brozmanova J, Manikova D, Vlckova V and Chovanec M: Selenium: a double-edged sword for defense and offence in cancer. Arch Toxicol 84: 919-938, 2010.

38 Lee KH and Jeong D: Bimodal actions of selenium essential for antioxidant and toxic pro-oxidant activities: the selenium paradox (Review). Mol Med Rep 5: 299-304, 2012.

39 Plano D, Baquedano Y, Ibanez E, Jimenez I, Palop JA, Spallholz JE and Sanmartin C: Antioxidant-prooxidant properties of a new organoselenium compound library. Molecules 15: 7292-7312, 2010.

40 Hazane-Puch F, Champelovier P, Arnaud J, Garrel C, Ballester B, Faure P and Laporte F: Long-term selenium supplementation in HaCaT cells: importance of chemical form for antagonist (protective versus toxic) activities. Biol Trace Elem Res 154: 288-298, 2013.

41 Guo CH, Hsia S, Shih MY, Hsieh FC and Chen PC: Effects of selenium yeast on oxidative stress, growth inhibition and apoptosis in human breast cancer cells. Int J Med Sci 12: 748758,2015

42 Trachootham D, Alexandre J and Huang P: Targeting cancer cells by ROS-mediated mechanisms: a radical therapeutic approach? Nat Rev Drug Discov 8: 579-591, 2009.

43 Benton G, Kleinman HK, George J and Arnaoutova I: Multiple uses of basement membrane-like matrix (BME/Matrigel) in vitro and in vivo with cancer cells. Int J Cancer 128: 1751-1757, 2011.
44 Rafferty TS, McKenzie RC, Hunter JA, Howie AF, Arthur JR, Nicol $F$ and Beckett GJ: Differential expression of selenoproteins by human skin cells and protection by selenium from UVB-radiation-induced cell death. Biochem J 332(Pt1): 231-236, 1998.

45 Mencalha A, Victorino VJ, Cecchini R and Panis C: Mapping oxidative changes in breast cancer: understanding the basic to reach the clinics. Anticancer Res 34: 1127-1140, 2014.

46 Cannon TM, Shah AT, Walsh AJ and Skala MC: Highthroughput measurements of the optical redox ratio using a commercial microplate reader. J Biomed Opt 20: 010503, 2015.

47 Herrera AC, Panis C, Victorino VJ, Campos FC, Colado-Simao $\mathrm{AN}$, Cecchini AL and Cecchini R: Molecular subtype is determinant on inflammatory status and immunological profile from invasive breast cancer patients. Cancer Immunol Immunother 61: 2193-2201, 2012.

48 Panis C, Victorino VJ, Herrera AC, Freitas LF, De Rossi T, Campos FC, Simao AN, Barbosa DS, Pinge-Filho P, Cecchini R and Cecchini AL: Differential oxidative status and immune characterization of the early and advanced stages of human breast cancer. Breast Cancer Res Treat 133: 881-888, 2012.

49 Panis C, Herrera AC, Victorino VJ, Campos FC, Freitas LF, De Rossi T, Colado Simao AN, Cecchini AL and Cecchini R: Oxidative stress and hematological profiles of advanced breast cancer patients subjected to paclitaxel or doxorubicin chemotherapy. Breast Cancer Res Treat 133: 89-97, 2012.

50 Pons DG, Sastre-Serra J, Nadal-Serrano M, Oliver A, GarciaBonafe M, Bover I, Roca P and Oliver J: Initial activation status of the antioxidant response determines sensitivity to carboplatin/paclitaxel treatment of ovarian cancer. Anticancer Res 32: 4723-4728, 2012.

51 Gumulec J, Balvan J, Sztalmachova M, Raudenska M, Dvorakova V, Knopfova L, Polanska H, Hudcova K, RuttkayNedecky B, Babula P, Adam V, Kizek R, Stiborova M and Masarik M: Cisplatin-resistant prostate cancer model: differences in antioxidant system, apoptosis and cell cycle. Int $\mathrm{J}$ Oncol 44: 923-933, 2014

52 Valko M, Rhodes CJ, Moncol J, Izakovic M and Mazur M: Free radicals, metals and antioxidants in oxidative stress-induced cancer. Chem Biol Interact 160: 1-40, 2006.

53 Valko M, Leibfritz D, Moncol J, Cronin MT, Mazur M and Telser J: Free radicals and antioxidants in normal physiological functions and human disease. Int J Biochem Cell Biol 39: 44$84,2007$.

54 Zobi F, Blacque O, Jacobs RA, Schaub MC and Bogdanova AY: 17 e- rhenium dicarbonyl CO-releasing molecules on a cobalamin scaffold for biological application. Dalton Trans 41: 370-378, 2012.

55 Barceloux DG: Selenium. J Toxicol Clin Toxicol 37: 145-172, 1999.

56 Reid ME, Duffield-Lillico AJ, Garland L, Turnbull BW, Clark LC and Marshall JR: Selenium supplementation and lung cancer incidence: an update of the nutritional prevention of cancer trial. Cancer Epidemiol Biomarkers Prev 11: 1285-1291, 2002.

57 Guo $\mathrm{CH}$, Hsia S and Chen PC: Distribution of selenium and oxidative stress in breast tumor-bearing mice. Nutrients 5: 594607, 2013.

Received July 1, 2016

Revised July 19, 2016

Accepted July 21, 2016 